\title{
THE INTERNATIONAL LEGAL STATUS OF ALBANIA FROM THE END OF THE LONDON CONFERNCE OF AMBASSADORS TO THE END OF THE FIRST WORLD WAR
}

DOI: $10.2478 /$ seeur-2014-0009

The international-legal status of Albania, provided by the London Conference of Ambassadors, differed from the one established by the National Assembly of Vlora, which declared it an independent, free country without other international legal obligations. The conference sessions decided on 17 December 1912 to give Albania the status of a vassal state under Turkey. Seven months later, the decision of 29 July 1913 established an independent state, but with a more "burdensome" condition. The statements regarding the status somehow shunned the international legal concept of the time. They do not explicitly identify the idea of an independent state. As stated in Article 1, "Albania is formed as an autonomous principality, sovereign and hereditary in order of primogeniture, under the guarantee of the six powers. The prince will be determined by the six powers." 1 As noted, the word used was not "independent", which would unequivocally give it legal status as an independent state (principality). It is evident that autonomy is not the equivalent of independence even as a concept or as status. It is inherently more limited than independence. It implies legal links with one or some other states, or conditioning of the vassal state's activities to the will of the suzerain state. It also implies the fulfillment of certain obligations imposed by it.

A.Puto, Çështja shqiptare në aktet ndërkombëtare të periudhës së imperializmit,

Përmbledhje dokumentesh me një vështrim historik, Vëll.II, (1912-1918), Tiranë,1987. 
For Albania, as designed in London on 29 July 1913 by the Great Powers, it seems that their idea of its constitution as an independent state had not yet been sufficiently mature. Therefore, apparently, as an expression of compromises that the Powers had done with each other, they found a vague formulation, according to which, only through an extended legal interpretation of a number of words and phrases, one could achieve indirectly the idea of a sui generis independence. The independence which the Great Powers agreed was not directly and clearly expressed, but it was a result of the merger and the interpretation of the words "autonomous, sovereign " etc. The word "state" is not mentioned in any of the provisions of this decision. In its place is mentioned the term principality. Even though, ultimately, it refers to a form and a certain type of state, as a political formation, it seems however like the Great Powers refused to apply the word "state" for Albania at the time.

They continue further defining the status of Albania as an independent state in blurred, and almost masked, terms, again by using other phrases and words. In the first article, the aforementioned, it was stated that the Albanian principality would be placed "under the guarantee of the six Powers", which, wanting to hold in their hands all the country's "reins", had decided to break every link of suzerainty between Turkey and Albania. They decided that the Prince of Albania would be appointed by them, the control of the civil administration and finance would be appointed to an international commission, which was to be known as the International Control Commission (ICC) composed of delegates of the six powers and a delegate from Albania. The commission would be charged with drafting a detailed project for the organization of all branches of the administration of Albania. After six months it would allocate Powers, by a report on the results of the work and conclusions concerning the financial and administrative organization of the country (Article 6). The conference took the decision on setting up a prince and the formation of a definitive national government, the existing local authorities and the gendarmerie, were to be placed under the control of the International Commission (Article 7) ${ }^{2}$. Public peace and order would be provided by an international gendarmerie that would rely on foreign officers who would be elected from the ranks of the Swedish Army. ${ }^{3}$

Despite the shortcomings and specific problems referred to above, it is clear that the decision of the 29 July 1913 made by the Conference of Ambassadors in London, in terms of the international juridical point of view, represented an act of recognition of an independent Albanian state as an entity

2 Ibid

3 Ibid. 
with attributes of international law. This meant that it had to accept Albania into the limited "club" of independent states at that time. This decision was made as a consequence of a range of circumstances. Some had to do with Albanians, who had announced publicly on November 28th the creation of their independent state, in uncontested legal-institutional forms. Some were related to the Great Powers themselves, whose relationship was undergoing some severe contradictions that were displayed prominently. By a careful examination of Article 7 of the Decision of 29 July and an expanded legal interpretation of its content, it can be concluded that the Great Powers, through this act, indirectly recognized de facto and de jure the government of Vlora. This was because it was the only government that had legitimate attributes to emerge as a national authority, and because it was chosen by a nationwide assembly of representatives. They had entered into several relationships with it, through their representatives accredited in Vlora, in the nation's capital, where the government had the seat. Other local authorities, which were mentioned by Article 7, were either nonexistent or had local tribal character with limited regional impact.

\section{Conditional international recognition}

The Albanian status, built according to models that the Great Powers had also applied in other cases, was characterized by some peculiarities, which, in some way, questioned its international juridical personality. Starting from the ways and forms of international recognition awarded to Albania, the Great Powers proceeded further with interference in its status. The London Conference of Ambassadors did not recognize Albania as a state for which Albanians had declared independence, but one created by the Great Powers, within a truncated territory. This approach wrongly provides a favorable opinion that the Albanian state was a creation, a product of Great Powers diplomacy. Foreign authors who have commented on the value of the July decision of the Conference of Ambassadors have exaggerated its importance and meaning. They have given to the constitutional act of the Albanian state a juridical power, which, according to them, was an "international act", at a time when the Albanian independent state was born and started its normal existence, within the terms and conditions which were more difficult at that time, on 28 November 1912. It had been created by Albanians, who thought that the state would include all the Albanian space which, before 28 November, was known as the four Balkan vilayets of the Turkish Empire. European diplomacy, through the Conference of Ambassadors, after fulfilling the wishes of neighbors to annex as much territory as they could, had reduced 
Albania into half of the space of its territories and left outside almost half of the Albanian population.

It was to this state that they granted a collective recognition, which came from a community of states and not by individual states, in the form of individual recognition. It was almost similar to the collective recognition that Great Britain, France, Russia and Turkey granted to Greece through the Treaty of Constantinople in the year of $1832^{4}$ or the one that the Great Powers had granted to Romania, Serbia and Montenegro, who broke away from the Ottoman Empire through decisions taken at the Congress of Berlin in $1878 .{ }^{5}$

With the decision of July 1913, the Great Powers granted a de jure recognition to Albania, and thus it was recognized as a subject of international law, accepted into the community of states of that time and established diplomatic relations. But, as noted, they reserved the exclusivity for themselves to build structures, to organize the political, economic, and social life of the nation, and to determine foreign external policy, to organize the army, gendarmerie, to draft and adopt a constitution-The Organic Statute of independent Albania. They took the responsibility to appoint and bring the head of the state to Durres, in a state that would hold on its fragile structures the Capitulations regime and the status of neutrality. In this way the "independence" of Albania will be placed practically in quotes.

As stated above, de jure recognition of Albania turned out to be sui generis. It was considered and accepted as a subject of international law, but put under international tutelage by truncating its sovereign attributes, without which a state could not be an independent state and a subject of international law.

The attitude held by the Great Powers for the international recognition of the Albanian state was based on the principles of the so-called constitutive theory, known also as the attributive theory of recognition. According to this theory the state is not considered a subject of international law at the time of its creation and its appearance on the world stage, but only when it gained international recognition by other countries, usually by the Great Powers ${ }^{6}$. The attitude held by them violated the legal concepts of statehood of the fathers of

4 Nguyen Quoc Dinh, Patrick Dailler, Alain Pellet, Droit International Public, 4 ème édition, Paris, Librairie Générale de Droit et de Jurisprudence, 2002, p.566.

5 Ibid.

6 Representatives of the constitutive theory, eg. Lassa Francis Lawrence Openhajm, Hersch Lauterpaht, George Sel, Hans Kelzen etc, defend the idea that only the recognition of "constitutional" state as the subject of international law, thus creating the necessary premise that it is entitled to rights and to fulfill obligations. See Nguyen Quoc Dinh, Patrick Dailler, Alain Pellet, op.cit, p.557. 
Albanian independence, some of whom were highly educated in law faculties of the best universities of Europe and had consolidated knowledge in the field of international law. In their dreams they saw Albania as all other states did for themselves, possessing all the necessary attributes for international recognition, needed by international law, immediately after the announcement of the Assembly of Vlora was declared, on November $28^{\text {th }} 1912$ and the beginning of state and administrative activities. They supported the status and its activities in the principles of declarative theory of recognition, according to which the state exists as a subject of international law at the time it appears as an independent state. The recognition for them was nothing more than an affirmation and declaration of a fact, a reality that already existed and was just waiting to be confirmed ${ }^{7}$. This was the reason why, without waiting for the answer to the demands of the international recognition that they had addressed to the Great Powers and other countries, the Albanian state had begun normal activities with its organs of central and local government, legislative, executive and judicial.

\section{Independent state under the charge of Capitulations}

While the Great Powers that recognized an Albanian state configured by them according to their interests that were far from those of Albanians, it can even be said based on peace and security in the Balkans, the act of recognition was followed by the imposition of a range of conditions. It was conditioned, as was mentioned, by the conservation of the system of Capitulations due to its affiliation to the Turkish imperial structures of government spaces. According to the decisions that were taken, they would continue to be applied even after its establishment as an independent state. The capitulations were a form of addiction among international law and represented a system of privileges and favors that the European Great Powers had imposed on the Ottoman Empire, as well as to some other countries of the Near East, Middle East and Far East, undermining somewhat their status as subjects of international law ${ }^{8}$. This system was acted upon even in the Albanian territory,

7 Representatives of the declarative theory, noted lawyers as Dionisio Anziloti, Charles Rousseau, Alfred Ferdross etc.say that the state as a subject of law exists, and there is present within its space territorial even in the international life at the moment of its birth. Nguyen Quoc Dinh, Patrick Dailler, Alain Pellet, op.cit, pp.557-558

8 Benedetto Conforti, Diritto internazionale, Editoriale Scientifica, VII edizione, 2013, p.197. Louise Fawcett, Marrëdhëniet ndërkombëtare të Lindjes së Mesme, UET/PRESS, Tiranë, p.27. 
for the simple reason that until the secession of Turkey, they were considered a territorial part of the Ottoman Empire. The Great Powers, while accepting the secession, did not judge it suitable to abstain from implementing the system of capitulations in the independent Albanian state. The reason seems clear: privileges and favors from the capitulations were in their interest. Therefore their representatives refused to liberate Albania from this "burden". They did not take into account the justifications advanced by Myfid Libohova (1876-1927), the Albanian representative in the discussions of the Organic Statute, which would have the role and value of a Constitution of the state. In the 41th session of the ICC, held in Vlora, on 31 December 1913, he asked for two of his remarks to be included in the session to the Article 4 of Chapter I. The text of the ICC stated his request, formulated as follows: "Asking the Commission not to hold the regime of Capitulations, which is a legacy of Turkish rule, on Albania. Due to political and international points, I think that Albania should be treated by Powers, its protectors, like other Balkan countries. In addition to these reasons, it is clear that Albania, sterling and impoverished as it is, needs a complete independence in the economic area, so that it could develop and be able to exist. Since the Albanian nation has received and accepted the sovereign appointed by the Powers and since Albania operates under an audit committee, which is the best guarantee that can be requested, the capitulations are a too heavy burden for the Albanian people and there is no reason why they could operate"

As seen, Libohova was underlying the European character of the Albanian state, the role of Prince Wied and the International Control Commission as relevant international guarantees for the respect of the rights of foreigners in Albania. The capitulations, which have their origin in the theocratic legislation and governance of Turkey, in disagreement with Western customs, no longer made sense to be implemented in Albania. Keeping them was against the principle of recognizing the independence by the Great Powers, while, as M. Libohova stated in the ICC, "The capitulations create many states within the state and derive many obstacles in the way of progress" $"$.

The Albanian representative insisted that the treaties, conventions and international agreements concluded between Turkey and the Powers could not be kept in force in Albania, with the exception of those that were in line with European public law and had a territorial character, because all treaties, conventions and international agreements signed between Turkey and the

9 A.Puto, Çështja shqiptare në aktet ndërkombëtare të periudhës së imperializmit,

Përmbledhje dokumentesh me një vështrim historik, Vëll.II, (1912-1918), Tiranë,1987, p. 495.

$10 \quad$ Ibid, p.603. 
Powers, with the exception of those that fell into the category mentioned, had been based on the theocratic character of the Turkish government and the organization of Muslim society, and in Albania the situation was quite different. The Albanian government would constantly try to adopt legislation inspired by the principles of modern Western civilization ${ }^{11}$.

Apparently convinced that his efforts were not achieving the proper result, the Albanian representative came up with the proposal to establish mixed courts, known and also experienced in other states that have accepted and applied the capitulations regime. This would mean that criminal or civil matters, that would have to do with foreigners, would be considered by some special court in which foreigners would participate, as well ${ }^{12}$. The ICC upheld Article 4 of the Statute and refused its cancellation or modification.

Mehdi Frashëri has pretended that he was the real author of the idea and even that the statements above that were registered in the ICC documents in the name of Myfid Libohova, were of his authorship. In his memoirs he says Myfid Libohova's declaration was made after the ICC approved the first version of Article 4 of the first chapter of the Organic Statute, which appears also in the appropriate documentation that reflects the proceedings of the 41th session of ICC. Mehdi Frashëri, who apparently was attached to the ICC as an adviser to the Albanian government representatives, shows that Myfid Libohova asked, in the second reading of the text of Article 4, to make the above statement, which he had formulated. M.Frashëri says that the capitulations were a violation because of the independence and sovereignty of the Albanian state ${ }^{13}$, he formulated a statement containing the reasons for the collapse of the capitulations, a statement which he gave Myfid Bey to read. The ICC decided to include it in the report of the session, "to present it to, as M.Frashëri said, the Great Powers by the delegates of the Commission, of each state" ${ }^{14}$.

To affirm its authorship, M.Frashëri, also explains that "this statement is also published in Thalozi's book in German ${ }^{15}$, and in Italian in Giannini's book" ${ }^{\prime 16}$. The depth of the content, the strength of argument and elegance of

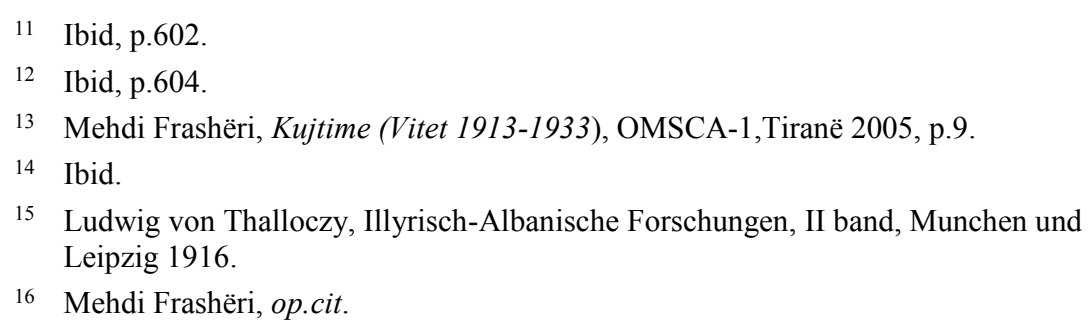


style can make us believe that the statement should have been a product of his training as a prominent lawyer, which emerges in a series of legal acts, of the royalist period, which keep the authorship thereof. There is no doubt of Myfid Libohova's personality, for he was a politician and intellectual with legal education.

The regimes of capitulations that were imposed on the Albanian state by the Great Powers were not kept as a formality. They felt that it would be necessary for them in certain situations, that they may develop in the future the new Albanian state, and that there were no verified delays although the state itself existed for a short period of time. Prof. Puto mentions a specific case that has to do with doubts about the participation of two Italians in the riots that occurred in central Albania in 1914. Colonel Thompson, the commander of the gendarmerie in the Wied government, ordered the arrest of the Italians. The Italian representative in Durres reacted immediately and demanded their release and the expression of an apology to Italy by the Albanian government. The request was fulfilled and in this case the capitulations regime practically went into action. ${ }^{17}$

The truncated position of the Albanian state sanctioned in Article 4 of the Statute (first chapter) of the Albanian state, which was prepared by the International Control Commission, in April 1914, expressly stated: "treaties, conventions and international agreements of any kind, connected between the state and foreign powers will continue to be in force in the Princedom of Albania. Changing or canceling the immunities and privileges, which are known to foreigners, according to the capitulations can be made only with the subsequent decision of the six Great Powers ${ }^{18}$ ".

Further, Article 169 sanctioned maintaining consular jurisdiction when determining that "consular prerogatives in the judicial field as they are stored under the Capitulations. ${ }^{19}$ " The Capitulations regime in Albania, as in all other countries where implemented, significantly impaired national sovereignty and the status of an independent state.

The end of the First World War and the international acts which were approved at that time for Albania, liberated it from the Capitulations regime. The decision of 9 November 1921, the Conference of Ambassadors of Paris,

17 Arben Puto, Pavarësia shqiptare dhe diplomacia e Fuqive të Mëdha, 1912-1914, Botimet Toena, Tiranë, 2012, pp. 534-535.

18 A.Puto, Çështja shqiptare... op.cit.

19 Ibid 
officially reaffirming the independence of Albania and the Silent Capitulations regime, scored their final official cancellation.

\section{Albania in the London 1913 Conference, a neutral state}

Collective recognition of the Albanian state, as a subject of international law was conditioned upon the acceptance of the status as a neutral state. The Great Powers decided that Albania would be accepted into the international community by holding the status of neutrality. Unlike the capitulations regime, which was a legalized opportunity to intervene in Albanian internal affairs, this status was much better. It should not be interpreted as a violation of its international personality legally. The idea of being a neutral state is an early roots initiative of Albanians themselves in their attempts to establish an independent state. It is documented at least since the last quarter of the nineteenth century, when a group of patriots from Shkodra, on 13 June 1878 addressed to the Minister of Foreign Affairs of Great Britain, Lord Beaconsfield, a letter that is known in Albanian history as the "memorandum of Shkodra citizens" ${ }^{20}$. The memorandum set out to the UK and to other great powers of the time the Albanians' desire to establish their own state, detached from the Ottoman Empire ${ }^{21}$. Although the discussions were for an independent state, it seems that the idea was limited to the creation of a vassal state under the common suzerainty of Great Powers, as happened with Bulgaria and Crete. It is understood that for this vassal state the allocation of the neutral status was required. This becomes quite clear from the content of points IV-VII, as well as a direct reference of the Memorandum which states expressly $A s$ a European guarantee is called necessary to protect the Danubian principalities, Switzerland and Belgium, so it is necessary that such support be given to new states that would arise under the Berlin Agreement ${ }^{22}$ (italics of the author).

Keeping in mind that Switzerland and Belgium were then states that enjoyed the status of neutrality, legally guaranteed by the Great Powers, it is

20 Memorandum sent to the English Prime Minister, Lord Beaconsfield, English representative to the Berlin Congress, with the request to protect the territorial totality of the Albania and to accept the status of an autonomous or independent state, at Akte të Rilindjes Kombëtare Shqiptare, 1878-1912, Botim i Institutit të Historisë të Akademisë së Shkencave, përgatitur nga Stefanaq Pollo dhe Selami Pulaha, Tiranë 1978, p. 21.

21 Ibid.

22 Ibid 
understood that representatives of the Albanian National Movement would seek the same status for Albania, and for its constitution as a neutral state. It was a carefully found solution, very appropriate and beneficial for Albania, because of the disorganized situation of the state. Albania could be more easily defended having a neutral state position, which was recognized and guaranteed by the Great Powers.

As Eqrem bej Vlora mentioned in his memoirs, the project of Albanian neutrality was also discussed before the London Conference of 1913, referring to meetings he held in Vienna in October 1912; he points out that the interlocutors had said that, if Turkey were to be defeated in the expected battles between it and its Balkan neighbors, then as soon as possible a representative assembly should gather, and should declare the independence and neutrality of Albania. ${ }^{23}$ The idea of a neutral Albania was acceptable even to the Austrians, the British and the Italians. A telegram from Edward Grey addressed to Sir Rennell $\operatorname{Rodd}^{24}$ on 15 November 1912, shows that it appeared to him as a personal proposal by the Italian ambassador. Grey wrote that: "he said, speaking from his own person, he thought it would be a good plan if Albania will hold a neutral status with a European guarantee. This would remove all suspicions of misunderstandings between Austria and Italy, and it would be much better than putting them in a privileged position regarding Albania." 25 A permanent neutrality would be required, prohibiting participation in any war or conflict that could develop near or in the region and abstention from participating in military alliances or international treaties that could lead to war.

Albania's neutrality enshrined in the London Conference, was specific, and similar to, but differing somewhat from, the neutrality of some of the other states of that period. It was the same with the neutrality of Switzerland, Belgium and Luxembourg because not only was it revealed and known, but also guaranteed by the six Great Powers, as stated in Article 3 of the decision of 29 July $1913 .{ }^{26}$ They had undertaken the obligation to respect its neutrality,

23 Eqrem bej Vlora, Kujtime, Vëllimi i parë 1885-1912, SHLK, Tiranë, 2001, pp.299 - 300.

24 British Ambassador in Italy, where he served until 1919.

25 Muhamet Shatri, Dokumente franceze për çështjen shqiptare në Konferencën e Ambasadorëve në Londër, 1912-1913, Vëll.II, Botimet Toena,Tiranë 2012, f.116-117

26 Sipas Illyrisch-Albanische Forschungen, Ludwig von Thalloczy, II band, Miinchen und Leipzig 1916, p. 173. Cited by A.Puto, Çështja shqiptare në aktet ndërkombëtare të periudhës së imperializmit, Përmbledhje dokumentesh me një vështrim historik, Vëll.II, (1912-1918), Tiranë,1987. 
not to touch it and to protect it from any attack. The position of neutrality was upheld by the Statute of the International Control Commission, in April 1914. It said: "Albania is neutral. Its neutrality is guaranteed by the six Great Powers. This neutrality does not preclude the right of Albania to take the necessary measures to protect its territory" 27 .

The wording included in the Statute, which normally would have been a breakdown and explanation of setting fixed at 29 July 1913 in the decision of the London Conference, transcends it. It did not only reproduce, but stipulated that Albania would be allowed to keep and develop its armed forces without any restriction on the number or its nature. Albanian neutrality was different from that of Luxembourg, whose treaty of London in 1867 prohibited the holding of armed forces except for the police force to maintain public order. In this regard it approached the neutrality of Switzerland and Belgium.

The issue of the type and number of the armed forces that Albania could have became a subject of debate during discussions and works of the ICC. The London decision provided for the protection of public order and the international organization of the gendarmerie, wording that some members of the ICC interpreted as a limitation of the Albanian armed forces, which could include many members of the gendarmerie, but not the army. Others, under the reasoning that the status of neutrality did not deny to the state the right to be protected in case of an attack, insisted that Albania have its own armed forces. The second view was accepted and included in the Organic Statute that was titled "on the militia", which meant precisely the regular army. 


\section{Why a neutral Albania?}

A question that can be raised is that of why the Great Powers imposed upon the Albanian state a permanently neutral status and guaranteed it. Assumptions and answers are different. One of them may condition the decision with the fact that the Powers were aware of the specific and difficult conditions in which the region and Albania existed at the time. Apparent contradictions in the Balkan clash between the European Powers isolated Austria- Hungary, Italy and Russia. Surrounding neighbors did not hide their ambitions for the annexation of various parts of its territory. To avoid any uncontrolled development in the future, the Powers judged that the status of neutrality would somehow calm the contradictions and at the same time would be a suitable shield against attempted annexation of Albania by neighbors. Otherwise the Albania that they were designing would hardly exist and develop normally under the circumstances of that time. It was in a delicate position because it was created in less than half of its territories. The rest were taken by neighbors, who burst in the Turkish-Balkan wars just to share its territories which, until 28 November 1912, were part of the Ottoman Empire. According to the principles of the rights of war of that era, Turkey emerged from the war as the loser and by this faced the consequences of responsibility, rewarding winners with territorial concessions which would effectively deal with the Albanian territories. Under these circumstances, they could not face preserving the fragile balances that were created through the decisions of the Conference of Ambassadors. Therefore they required additional elements to strengthen the problematic status of the Albanian state.

This affected the feelings of distrust towards Albanian nation-building skills, while those stimulated by daily performances of conflicts between some leaders of the Albanian political movement, which actually featured the negative traditions of the Balkans. Typical here were the actions of one of the more different and influential individuals-Esat Pasha Toptani. These performances added doubts, and perhaps even fear of the risks of unforeseen developments in Albania, if it had been any eventual possibility to support and fight with either one or another force, or any other neighboring country. The insurance of the position of neutrality should be understood as a commitment on the part of the Great Powers to take on defense, a commitment legally formalized through this legal finding.

From a legal and political status Albanian neutrality cannot be deemed as a deficiency or violation of its position, because that does not restrict its 
identity as a subject of international $\operatorname{law}^{28}$. Rather, in a sense, it could be considered as an advantage because the Great Powers undertook its defense if Albania were the subject of attack by others. There is no doubt they took this commitment more in their interest, so they had no preoccupation about the Balkans, and so they could think of it as a stabilized region. This was openly expressed by Edward Grey, in the last day of the Conference of Ambassadors, when he declared in the House of Commons that: "I know very well that when everything will become known, this solution in many points will give rise for strong criticism from anyone who knows the country but the goal has been to maintain the agreement between the Great Powers, and if the decision on Albania has provided this, then it has done the best job in favor of peace in Europe $^{29}$

However, it didn't take a year and on 28 July 1914 the First World War began. A few months later the same Great Powers, who recognized an independent Albania - with set borders, declared to be neutral, and to be defended if attacked by others - they now attacked themselves, conquered and partitioned it between them. The consequences of invasions, which canceled the status of neutrality, were heavy and expensive for Albanians.

\section{When did Albanian neutrality end?}

To the question of when Albania ceased being a neutral state there are many answers. One of them relates to formal-legal aspects, and namely an act specifically mentioned in the diplomatic history of the Albanian issue and in general the diplomatic activity of the Great Powers at the beginning of the First World War and during it. It comes to the so-called Secret Treaty of London, signed on the 26 April 1915 between Great Britain, France, Russia and Italy. Referring to a complete diplomatic act in Berlin, nearly a quarter century earlier, the Treaty of Third Tripartite Alliance between Austria Hungary, Germany and Italy, signed in Berlin on the 6 May 1891, dealt with the position of Albania after war $^{30}$. The appendix of Article 5, of the secret

28 Hugh Beach, Secessions, interventions and just war theory: the case of Kosovo, në Pugash Occasional Papers,I, February, 2000, (www.pugash.org/reports/rc.beach.htm).

29 Edward Grey, Speeches on Foreign Affairs, London 1913, p. 212

30 With this Treaty Italy became the third power in the Balkans, along with AustriaHungary and Russia, with specific goals to Albanian territories. (Article 7 of the Treaty of Third Tripartite Alliance). After the outbreak of World War I and the occupation of Serbia by Austria-Hungary, Italy, under Article 7 of the Treaty of May 6, 1891, demanded compensation, namely the cessation of interest in Albania by AustriaHungary. After the refusal of the Austro-Hungarians, the Italian government announced 
Treaty of London of 26 April 1915, said: "The four Allied Powers, will share the Adriatic lands, mentioned below, between Croatia, Serbia and Montenegro. In the lower Adriatic (in the region of interest of Montenegro and Serbia), will cover the whole coastline that runs from Cape Plamkës up the Drini river, and that includes the important ports of Split, Dubrovnik, Kotor, Tivat, Ulcinj and Shëngjini. While the port of Durres will be submitted to an independent Muslim state of Albania". Section 6 set that "Italy will take over full sovereignty of Vlora, Sazan Island and surrounding territory with a sufficient stretch out toward the North and East of Vjosa, close to the Northern border region of Tsamouria (Çamëria, in albanian) in the south to ensure the protection of these points". Article 7 defined that: "If Italy would take Trentino and Istria in accordance with Section 4, along with Dalmatia and the islands of the Adriatic within limits set out in Article 5 and the Bay of Vlora (Article 6) and for the central part of Albania would be reserved for the creation of a small autonomous neutral state, Italy will not oppose the separation of northern and southern Albania between Montenegro, Serbia and Greece if this part would be desired by France, Great Britain and Russia. The coast, from the Southern border of Vlora Italian territory (Article 6) to Cape Styllo will be neutralized. Italy will be charged with representing the Albanian state in dealings with foreign powers. Moreover Italy agrees to leave the territory of Albania in the East sufficient to ensure the existence of a border between Greece and Serbia to the west of Ohrid Lake" ${ }^{31}$.

As noted, the Great Powers sanctioned the change of the borders set by them in London and decided upon the fragmentation and splitting of a significant part of Albania, which was recognized as an independent state. Everything was done because of the interests and territorial ambitions of Italy, Serbia and Greece, to attract them to the Entente, militarily aligning them in the First World War.

The treaty was signed by Edward Grey, Paul Cambon, Marquis Guglielmo Imperiali and A.K. Beckendorf, respectively on behalf of Great Britain, France, Italy and Russia. With their signatures they canceled substantial parts of international acts for independence, neutrality and the borders of Albania, which they had signed a year or so earlier in London, along with the representatives of Austria-Hungary and Germany.

its departure from the Tripartite Alliance (Central Powers). While Italy along with Austria-Hungary talked about the Albanian issue, they held talks on its merger with the Entente powers cordial, which ended with the Treaty of London of 26 April 1915.

31 Joseph Swire, Shqipëria, ngritja e një mbretërie, Dituria, Tiranë, 2005, pp.209-210. 
For the scenario envisaged in the secret Treaty of London to Albania Nicole Guy said, "When the Albanian issue will not threaten peace and balance between great and small powers, they, the Powers, will leave Albania" ${ }^{32}$. Even more accurate was Edith Durham, who wrote at that time that "the born state of Albania will feed wolves to be saved by its creators" 33 .

\section{The London Conference of Ambassadors (1913) and the Treaty of London (26 April 1915)}

Within a one year period of time, two forums of diplomacy of the Great Powers, the London Conference of Ambassadors and the Treaty of London sanctioned decisions that stand opposite and counter to each other, and which deserve a theoretical-legal treatment (approach) to explain the legal basis and their legal value. The above issue is treated most on the field of legal doctrine, as a subject of a study with a theoretical character, which took the form of a tough diplomatic discussion on international forums at the end of First World War. In the field of doctrine it will not be difficult to make interpretations and find answers that, as the case and interests, could be negative or affirmative. The policy of the Great Powers to improvise the judicial appearance for unfair and arbitrary settlements was never difficult. ${ }^{34}$ In the past the right was on the side of the stronger formally as well.

At the Peace Conference, the work of the League of Nations and the Conference of Ambassadors in Paris the representatives of neighboring countries, sometimes supported by representative of Great Powers, tried to argue legally that the Treaty of London attacked and annulled the legal value of acts of 1912-1913 for Albania. As such, it would prevail in preference to the decisions of the Ambassador Conference and the previous discussions of the Albanian issue.

In Paris at the Peace Conference some of the victorious powers of the Entente that had signed the Secret Treaty of London insisted on the annexation of Albanian territory. Rome claimed Vlora city and the protectorate on the "autonomy of the Albanian State", which would be formed in the Centre of Albania, according to the stipulations of the London Treaty. Greece wanted

32 Nicole Guy, Lindja e Shqipërisë, Nacionalizmi etnik, Fuqitë e Mëdha të Luftës së Parë Botërore dhe Lindja e pavarësisë së Shqipërisë, Botime Pegi, Tiranë 2012.op.cit. p.108.

33 Edith Durham, Brenga e Ballkanit, p. 258, cited by Nicole Guy, op.cit. p. 108.

34 A.Puto, Historia diplomatike e çështjes shqiptare, 1878-1926, Botimet Dudaj, Tirane, 2010 . 
Korça and Gjirokastra, while the representative of Serbian-CroatianSlovenian Kingdom, said that they would take the part that "belonged" to them, even if any other state would be recognized the right of occupation and the right of protectorate over Albania or on any part thereof.

On 9 December 1919, representatives of England, France and USA, making efforts to find a solution, published a memorandum whereby, pursuant to the London Treaty of 1915, recognized for Italy the full sovereignty of Vlora and its province, as well as truncating the Albanian state's mandate. The borders of the Serbian-Croatian-Slovenian Kingdom would remain those of 1913, but it would recognize the right of exit trade in Northern Albania. Greece would annex the region of Gjirokastra in the Western part of Nemërçka Mountain, Tepelena and Kurveleshi. The issue of Korça would be discussed later. With the memorandum of 13 January 1920, representatives of England, France and Italy announced a compromise, under which Albania was partitioned between Italy, Greece and the Serbian-Croatian-Slovenian Kingdom, as anticipated in the Secret London Treaty of 1915.

The delegation of the Albanian Government to protect the existence of the Albanian state, in two memorandums submitted to the Peace Conference in February 1919, noted that the independent state of Albania - recognized by decisions of the London Conference of Ambassadors - cannot be submitted for discussions. All that should be done was to return the territories detached by injustices committed by the Berlin Congress and by the London Conference of Ambassadors. The legitimacy of this request was based on the fact that the approved decisions of the Conferences were not abrogated ${ }^{35}$.

The Greek party contested the legitimacy of these agreements and affirmed that the Firenze Protocol noted the borders of Albania, but they were just on a map and were not set on the ground ${ }^{36}$. Greece did not recognize them because the Secret Treaty of London foresaw a stipulation, by which de facto the decisions of London in 1913 had become invalid. Albania's neutrality was violated after its participation in the First World War. ${ }^{37}$

Judging the issue under the context of the time, and taking into consideration the developments in Albania and the region during the period of the First World War, it could be said that the Secret Treaty of London had not

35 AQSh,Fondi 14,dos.41/1, pp.417-420. Memorandumi shqiptar dërguar Lidhjes së Kombeve, 25 qershor 1921.

36 AQSh,Fondi 14, dos.216, pp.3-10. Memorandumi grek dërguar Lidhjes së Kombeve, 25 qershor 1921.

37 Ibid, p.5. 
the necessary legal-institutional authority to abrogate the decisions of the Ambassadors Conference of 1912-1913. The events in Albania during the First World War, did not and could not lead to the extinction of Albanian state and annulment of decisions of the Assembly of Vlora and the decisions of the Conference of Ambassadors. The Secret Treaty of London was an act of socalled secret diplomacy, which after less than six years would be considered unacceptable. The U.S President W. Wilson, in 1918, denounced it as an unacceptable practice, ${ }^{38}$ and the statute of the League of Nations officially would adopt a negative ${ }^{39}$ policy toward this secrecy, as it caused serious consequences for people and different countries. On the other side it was a vicious legal act, because its signatories were only two-thirds of the countries that approved the decisions of London Conference in 1912-1913 and not a full quorum.

As a rule, international law has sanctioned the principle that the international multilateral treaty can be changed, amended or abrogated with the same quorum that signed it and is in force, if in its text it is not otherwise provided. The London decision for the Albanian statute and its permanent and guaranteed position of neutrality was stated by six Great Powers, as well as two other decisions for the delimitation of northern borders and North-East and South and South-East of it, were approved by consensus (so by the unanimous vote of six Great Powers, participants of the Conference). Therefore they cannot abrogate with a two-thirds majority, as happened with the Secret Treaty of London. They remained legally in force. This happened because ongoing attempts undertaken in the Peace Conference in Paris in 1919-1920 to implement the Secret Treaty of London ended with no success. Except for the reality on the ground, one of the formal-juridical reasons should have been the difficulty of juridical-international character to justify legitimacy and judicial power.

Regarding the invalidity of the London Treaty a document was found in the League of Nations archives, but also in the Albanian Central State Archive, entitled Albania. It was produced by institutions of one of the state signatories of the London Treaty. In the part "Is the Government recognized de jure or de

38 Bruno Cabanes, Le Vrai Échec du traité de Versailles, në L'Histoire, n 343 , juin 2009, p. 86 (ISSN 01822411)

39 Article 18 of the League of Nations Statute, determines: "Every treaty or international engagement entered into hereafter by any Member of the League shall be forthwith registered with the Secretariat and shall as soon as possible be published by it. No such treaty or international engagement shall be binding until so registered." The Covenant of the League of Nations (Including Amendments adopted to December, 1924), Yale Law School, C 2008 Lillian Goldman Law Library 127 Wall Street, New Haven, CT 06511. 
facto, and by which states", apparently, in the reference of expulsion of Italy from Albania in the end of the Vlora War, on July-September 1920, it said: "In the end (of the First World War) the Italian government decided to give up entirely on its rights over Albania and the Treaty of 1915, in this sense, remained without power" (text with italics of author) ${ }^{40}$. Because of the Albanian resistance, and the positive role of the USA and of President Wilson, none of the projects presented at the Conference remained unimplemented and Albania was saved from a further partition or perhaps from its disappearance on the political world map.

\section{Discussions on the status of Albania in the League of Nations}

This issue was re-opened again in the League of Nations. In the long procedural battle that took place in the admission subcommittee and its Assembly, in its review of the application for the admission of Albania, the extreme nihilistic character of the Albanian statehood emerged with particular vehemence. The representatives of neighboring countries were particularly concerned to deny the existence of the Albanian state. The representative of Greece stated that Albania had not yet arranged to permanently ${ }^{41}$ set its borders. The Treaty of London of 26 April 1915, had decided about the changing of borders. Abusively manipulating concepts of international law, he insisted that the Treaty of London had cancelled the decisions of the Conference of Ambassadors, since it was signed by nearly all the great powers which had adopted the decisions of the London Conference, missing only Germany and Austria, whose rights had ceased to exist after the Treaty of Versailles and Saint Germain. He also said that between Albania and Greece, there had not been signed any bilateral agreement on borders, with the exception of some minor practical adjustments that were made. ${ }^{42}$

The representative of Serbia, a state also with many claims on Albania, stated that Albania did not have any state borders, had no internationally recognized government, etc. According to him it was just an international

\footnotetext{
40 AQSH, P.14,v.1920, D. 210, fl. Nr. 3

41 Société des Nations (SdN), Actes de l'Assemblée 1921, Séance plénière, Genève 1921, pp. $668-670$

42 Ibid.
} 
problem, "an embryonic state" and as such should not be admitted into the League of Nations. ${ }^{43}$

In support of the anti-Albanian attitudes of the neighboring countries there were also the representatives of France and Great Britain. The French delegate Viviani stated that the Great Powers had not yet determined the status of Albania and that its admission to the League of Nations would be a challenge to the Great Powers. The British representative also objected by saying that Albania is not recognized by the Powers ${ }^{44}$.

A negative role was played also by the statement of the representative of Italy, who presented relations with the Government of Tirana as informal ones. He concluded that "the Italian government did not recognize the Albanian government neither de jure nor de facto" 45 . In these difficult days, considering its legal and international position during World War I, Albania got the support, with consolidated arguments, of the prominent personalities in the field of politics and international law doctrine. Two of them were representatives of the British dominions, South Africa and Canada ${ }^{46}$, respectively, Lord Robert Cecil and Wesley Newton Rowel1 ${ }^{47}$.

The eminent British lawyer Lord Robert Cecil, in his occasional interventions in the discussions at the League of Nations, made a prominent point from the international legal standpoint about the legal effects of the secret Treaty of London regarding the status of Albania and its borders,

43 Ibid.

44 Société des Nations. Actes de la première Assemblée, 28ème séance plénière du 17 décembre 1920, p. 646. Shih gjithashtu edhe Mandelstam, André. La Société des Nations et les Puissances devant le problème arménien, Paris, Pédone, 1926; rééd. Imprimerie Hamaskaïne, 1970. Sommaire Chapitre VII: La Question arménienne devant la première assemblée de la Société des nations André Mandelstam (Albanie, p. 12.)

45 Société des Nations. Actes de l'Assemblée 1921, Séance plénière, Genève 1921, pp. 668670

46 SdN, Actes de la première Assemblée, 28 ème séance plénière du 17 décembre 1920, Genève, 1921, p. 646. Actes de la première Assemblée, Séances des Commissions de la première Assemblée, Genève, 1921, t. II, pp. 190,198.

47 Edgar Algernon Robert Cecil (1864-1958) lawyer, member of the British parliament and cabinet of ministers, one of the architects of the creation of the League of Nations, Nobel laureate for peace (1937). Since setting up the formal termination of the League of Nations, his public life was devoted to it. Newton Wesley Rowell, (1867 - 1941) lawyer and politician. Special mention to the undeniable contributions to the work of the First Assembly of the League of Nations. 
determined by the decisions of the London Conference ${ }^{48}$. Lord Cecil's advocacy was distinguished not only for its eloquence, elegance and exceptional oratory, but also for its strong international legal argument. $\mathrm{He}$ gave a detailed description of the Albanian case, rejecting the argument that the secret Treaty of London had invalidated the decisions of the Conference of the Ambassadors, stressed that the new treatment of the Albanian case, which was proposed during the negotiations of the Great Powers to regulate Europe politically after the First World War, remained only a proposal never put into effect. He argued that, from the legal standpoint, a proposal made by some force cannot abrogate a treaty formally signed by other Powers. This, according to him, would undermine the foundations of international law, and would oppose the binding character of treaties, whose preservation was essential for the League of Nations ${ }^{49}$. Referring directly to Albania's case he said that it had not ever lost its position as a state in legal terms, and no one was authorized to deny or doubt her situation clearly defined as a European ${ }^{50}$ state. The special rapporteur for Albania, Lord Robert Cecil, who was also Chairman of the Second Sub-commission for admissions, said that Albania's application constituted a special case. He disagreed with the Serbian representative's claim that after the war the Albanian state ceased to exist. Its status could not change either from the occupation of its territory by the warring forces, nor from the secret war treaties or different projects made in the corridors of the Peace Conference. Though the treaties remained only on paper, they were never implemented, they were proposals only, projects and, therefore, did not affect Albania's position as an internationally recognized state. $^{51}$

Following the above reasoning the Canadian delegate Rowell expressed himself against the practice of entering into secret treaties for the division of small and unprotected states ${ }^{52}$. Cecil's and Rowell's reasoning about Albania's status as determined by the Conference of Ambassadors, retaken under consideration, unjustly and without legal effect by the secret Treaty of London, gave a helping hand to the Albanian delegation which defended at the time the case of admission of Albania in the League of Nations. It was particularly important for the affirmation of its existence as an independent

\footnotetext{
48 Société des Nations. Actes de l'Assemblée 1921. Séances plenieres Genève 1921, pp. 668-670.

49 SdN, Actes de la première Assemblée, Séances des Commissions de la première Assemblée, Genève 1921, t. II, p. 190.

50 Ibid

51 Ibid.

52 Ibid.
} 
state, as a subject of international law, that its political and legal status was defined and recognized internationally.

In any legal-international overview, what happened to Albania during the First World War, cannot be equated with extinction or loss of its attribute as a state. The doctrine of international law states that if an entity loses one of the attributes of state, it does not mean that it ceases to exist as such. For example, a lack of government action in a state as a result of invasion or intervention from a state or a coalition of states does not mean it is not a state. Occupation and acquisition of territory by force is an illegal act. The territory acquired in this way does not belong to the invaders. As a rule what ceases to exist as a result of the unlawful use of force are the governments not the states ${ }^{53}$. "Military occupation does not touch statehood - ex hypothesi the invader cannot transpose territorial sovereignty, although statehood attributes are violated. It is not fair to describe governments in exile as states without territory or people, when their displacement is caused by a military invasion. States as Slovakia and Croatia, that were created as a result of threat or use of illegal military force, respectively in 1939 and 1941, were recognized by few countries" ${ }^{\prime 4}$.

Related processes occurred in Albania at the time of the War, in the period $1914-1918$, which were repeated in the period of World War II, from 1939 to 1944. In those days there was not a voluntary submission of the sovereignty of Albania to another country or a merging of it into an entirely new organism. It was an actual illegal invasion, justified under the application of an international legal act which also was illegal. Canadian delegate Rowell said that: "Conscientiously, I cannot consider legitimate and entitled any group of countries that decide to divide another state, which is weak and undefended, for which they have even guaranteed neutrality" ${ }^{55}$. Lord Cecil rejected the thesis of the representatives of neighboring countries, that the secret Treaty of London had invalidated decisions of the Conference of Ambassadors. He said that Albania was recognized before the war and had never lost its position as a state. Cecil rejected the claim of the Serbian representative in the Commission that the war had wiped out the Albanian state that had existed before its outbreak, arguing that, when a country is recognized internationally,

53 Martin Dixon, E drejta ndërkombëtare, AIIS, Tiranë, p. 178.

$54 \quad$ Ian Brownlie, op. cit, p.78.

55 Actes de la première Assemblée, 28ème séance plénière du 17 décembre 1920, p. 646. See also the Mandelstam, André. La Société des Nations et les Puissances devant le problème arménien, Paris, Pédone, 1926; rééd. Imprimerie Hamaskaïne, 1970. Sommaire Chapitre VII: La Question arménienne devant la première assemblée de la Société des nations, André Mandelstam (Albanie, p. 12.) 
it cannot disappear either from the invasion of foreign armies, or from the fall of the authority of the government, as long as its citizens preserve a national consciousness and aspire to an independent existence, as was the case with the Albanian people. On the contrary, he argued, many other countries that had been for a long time under foreign occupation were already members of the League, and they should have not been admitted ${ }^{56}$.

In practice the decisions of the London conference of 1913 about Albania were violated by the Great Powers and other warring parties, who occupied different parts of its territory during the First World War ${ }^{57}$. In this way, what had been adopted no later than a year before, the political independence, its borders and the status of neutrality, which remained on paper, were violated.

\section{Albania's attitude towards its neutral status}

The issue could be raised and reviewed also from another angle. What was the Albanian position? Did Albania join with some of the sides in the conflict? Did Albania violate the status of neutrality that the Great Powers had given it in 1913? What was the Albanian position during the First World War until the time of the adoption of new decisions post war referring to Albania?

The answer to these questions, approached and interpreted differently in international forums at the end of the First World War which reviewed the political developments in Albania at the time and in the surrounding countries, was important for the fate of the Albanian people. At that time there were some attitudes, not always unique. One of them is expressed by Fan Noli, who in a presentation on behalf of the Pan-Albanian Federation "Vatra" at the Conference of suppressed and subordinated Nations in Washington DC, in 1918 offered an interesting explanation. He tried to defend Albania's position during the War and the end of it by comparing it with Belgium. Noli said that the case of Albania "has some similarities with Belgium, with the difference

56 SdN, Actes de la première Assemblée, 28e séance plénière du 17 décembre 1920, Genève 1921, p. 646.

57 In the Memorandum of the Delegation of the Temporary Government of Durres presented at the Peace Conference, Paris February 12, 1919, it was said: "Its neutrality was guaranted by Great Powers, was violated by combatant armies and similarly to Belgium, Albania suffered all horrors of invasion ."Lufta e popullit shqiptar për çlirimin kombëtar, 1918-1920, II, Prepared by Muin Çami, (përgjegjës), Hydajete Luga (Bejtja), in collaboration with Dhimitër Andoni, Mediha Shuteriqi dhe Zekeria Rexha, Tiranë, 1975, pp. 91-97. Turhan Pashë Përmeti, Shqipëria përballë Konferencës së Paqes, Paris, 1919, Ble i Parë, Roma, 1919, Eugen, Tiranë 2007, pp.119-120, 
that the first is more tragic and hopeless. The international treaty that guaranteed the independence and neutrality of Albania was as solemn as the one with Belgium. Belgium has been overrun only by Germany. Albania has been occupied by Greeks, Montenegrins, Serbs, Austrians, Bulgarians and Italians. Albanians did not provoke their attackers and neither invited them, their only guilt is the possession of land and a coastline coveted by their neighbors. Belgians sufferings fade when compared with the Albanian martyrdom during this dark period of occupations. Belgians may struggle against invaders, because they still have an army and are backed by powerful allies; Albanians are hopeless because they do not have an army to defend themselves. Belgians may protest although the non neutral powers can be indifferent to their appeals, and Albanians must endure their agony in silence, because they have neither friends nor defenders, and for them it can be applied the famous verse of Alfred de Vigny's "Souffre et Meurs et sans parler"! Belgians can hope to regain independence after an Allied victory and other races oppressed may have the same hope after a victory over Teutonia. Albanians cannot feed such expectations. If the Allies win the war, Albania may be annexed by Italy; if the Germans win, Albania could be annexed by Austria. Therefore we Albanians are strictly and absolutely neutral and hope that this war will end with a draw, and that none of the warring parties will completely overwhelm the other side" 58 .

A different approach was one that was adopted by the government of Durrës. The memorandum that was directed to the Peace Conference on 12 February 1919 stated that the Albanians fought alongside the Entente forces. “... The Albanian people, did not avoid their duty towards the Entente... Happy that they gave their modest contribution to the cause of freedom, Albanians come today to ask confidently the Areopagus of the world, of claiming their rights, ... We seek the independence and territorial integrity of Albania and respect for the sovereign rights of the Albanian people" ${ }^{\text {" }}$.

58 Çështja shqiptare Fan Stilian Noli, Një paraqitje e Federatës Pan-Shqiptare "Vatra" në Konferencen e Kombeve të Shtypura dhe të Varura në Washington D.C. 1918 (?). Somerset Record Office, DD/DEU/35, 1919. Quoted in ed. "Phoenix".

59 Memorandum of Delegation of the Temporary Government of Durrës presented at the Peace Conference Paris, 12 February 1919, Lufta e popullit shqiptar për çlirimin kombëtar, 1918-1920, II, Prepared by Muin Çami, (përgjegjës), Hydajete Luga (Bejtja), in collaboration with Dhimitër Andoni, Mediha Shuteriqi dhe Zekeria Rexha, Tiranë, 1975, pp.91-97. Turhan Pashë Përmeti, Shqipëria përballë Konferencës së Paqes, Paris, 1919, Ble i Parë, Roma, 1919, Eugen, Tiranë 2007, pp.119-120, and Çështja shqiptare në aktet ndërkombëtare pas Luftës së Parë Botërore, prepared by Arben Puto, Albin,Tiranë, 2001, pp. 91-97. 
The Albanian delegation of the Government of Durrës presented to the secretariat of the Conference the Albanian demands for reaffirmation of their state, recognized by the Conference of Ambassadors in London in 1913 and for guaranteeing the territorial integrity within historical ethnic boundaries ${ }^{60}$. In this context, they urged the Peace Conference to restore Albanian territories that the London Conference had passed unfairly to Montenegro, Serbia and Greece, where about one million Albanians lived ${ }^{61}$.

The government, at the Congress of Lushnja, in one of its decisions adopted in February 1920, declared that Albania was a neutral country and was neutral during the First World $\mathrm{War}^{62}$.The solution to this issue that the Lushnja Assembly gave, answers to the truth and expressed best interests of the Albanian state at that time. Albanians cannot be considered as a belligerent in the First World War, neither de facto nor de jure. During the war in Albania there was no central government or public authority to make any official act regarding the entrance of Albania into the war. The Great Powers that militarily occupied territories also violated its sovereignty. Participation in the war of some particular individuals on one side or the other does not represent a broad movement of the people in general. Albania did not participate in war with any of the two warring blocs. It cannot be held responsible for violations of its neutrality by others.

In this chaotic situation, very complex, with risks and unexpected events, the Albanians tried to organize themselves and to unite for their homeland. As Robert Larry Wodel rightly says "The main factor that saved Albania from its final partition was the action of Albanians themselves in their country's defense. Finding no support from the peacemakers of Paris, Albanian leaders formed a government in January 1920 and rose up and thrust out of the country all foreign armies ${ }^{63}$ in the point of view of the Great Powers, an independent Albania would be undesirable and should be partitioned between Italy, Yugoslavia and Greece, while maintaining a part of Middle Albania, with nominal independence, under the care of a Great Power" ${ }^{64}$.

60 Arben Puto, Historia diplomatike e çështjes shqiptare, Akademia e shkencave, Albin, Tiranë, 2003, fq.275-277.

61 Ibid., p. 95-96.

62 Lufta e popullit shqiptar për çlirimin kombëtar, 1918-1920, II, Prepared by Muin Çami, (përgjegjës), Hydajete Luga (Bejtja), in collaboration with Dhimitër Andoni, Mediha Shuteriqi dhe Zekeria Rexha, Tiranë, 1979, p. 58

63 Robert Larry Wodel "Problemet e shqiptarëve gjatë Konferencës së Paqes 19191920".

64 Ibid. 
The outcome of the Peace Conference would not mean the end of the claiming of territories by neighbors to Albania, nor the end of the false charges of the violation of its neutrality. They were now to be moved to the League of Nations in Geneva. To these charges the Albanian representatives responded with consistent legal arguments. It is worth noting a fierce debate, held at the 25 June 1921 session, where Noli, as Chairman of the Albanian delegation, rejected the legal validity of the secret Treaty of London towards Albania. He said that the treaty, not only was not officially published, but was replaced by the Treaty and Protocol of Rapallo at Tirana, according to which Italy give up Vlora and the right of mandate over Albania. Noli said that Albania had not violated its neutrality during the war. Esat Pasha had been governing Albania and was never known as an ally by the Entente ${ }^{65}$

\section{The decision of the Conference of Ambassadors in Paris, November 9, 1921}

The Great Powers would not delay in demonstrating within a short period of time that they acted in their narrow interests and not for the benefit of the Albanian people. An episode dated 4 March 1919, occurred in the Commission created by Allied Supreme Council of the Peace Conference in Paris which clearly demonstrates the perspective that the Powers had towards Albania's political future and what their considerations about Albanians were. Discussion centered on territorial claims submitted by the Greek Prime Minister Eleftherios Venizelos, through the Memorandum dated 30 October 1918, where Albanians were treated as people with no right to judge and decide their fate and their future. The British representative Sir Eyre Crowe, talked about the future political status of Albania, which he called "highly sensitive". He cited the Gjirokastra Proclamation, published in June 1917 by the Italian ${ }^{66}$ command, that "proclaims an Italian Protectorate over Albania". Referring to the projects discussed at the conference, he raised the question: "the question whether is to give Albanians their independence, or just to learn to which nation the land will be transferred, Greece or Italy?" The population, he said, consists of a large majority of Greeks. Is Italy ready to extend its protectorate over this population, a large majority of which consists of

65 AMPJ,viti 1921, dos.45, p.74. Diskutimi i Fan Nolit në sesionin e 13 -të të Lidhjes së Kombeve, 25 qershor 1921.

66 A. Giannini, op. cit pp. 39-40. 
Greeks?" ${ }^{\prime 67}$. With this he seemed to mean that Italian protectorate could be accepted on the Albanian population, but not on the Greek one. Therefore the solution seems to be the assigning of this province to Greece.

The question obviously expressed ignorance of the truth and of course was an irresponsible attitude in dealing with the fate of peoples who a few years earlier had declared their independence, which was recognized and guaranteed by the Great Powers, one of which was also the state of this delegate. In its essence it meant that they, the Great Powers and their clients, could do whatever they wanted with the Albanians and Albania. The British representative replied to the Italian delegate De Martino, who said it is not absolutely correct that Italy has declared a protectorate. It is true that there was a military proclamation on 3 June 1917, in which the military authority used the word "protection". But it was rectified in a speech that the minister of foreign affairs held in the Chamber, a few days later, where he clarified the view of the Italian government. The proclamation, he continued, is regarded as a momentary act of military authority in circumstances of war, which cannot engage the Italian government after the war. However, he did not fail to make clear the intention of Italy towards Albania, which he identified as another power that cares about Albania "just regarding foreign relations", in the new circumstances and in a new area. He used as evidence the Treaty of London of 1915, which charged Italy to represent Albania in foreign relations ${ }^{68}$, given the international mandate as a form of legal-international agreement which was developed by the Conference of Peace and was included in the Statute of the League of Nations, which was an integral part of the Treaty of peace. The idea of "care" of Italy over Albania, pointed to by the Italian representative Martino, meant precisely its mandate over it. Although he said that "the Italian Government does not require a protectorate over Albania", he referred instead to the idea of "care", which would have as a formal order to cover the League of Nations. U.S. Representative Day in the debate spoke "to establish a protectorate over Albania or, more correctly, the League of Nations", showing a preference for a type of international assistance under the control of the League of Nations. The use of term "protectorate" instead of "mandate", indicated that the project was not yet clear. The British representative, Crowe, said that the League of Nations would exercise its authority through a mandatory power, and if it did this mandatory force would be Italy, which would be very much like the protectorate. U.S. Representative Day, disagreed and said that "to give to a state of League of Nations a mandate

67 Commission chargé d'étudier les questions territoriales intéeressant la Grèce, Parigi, 4 marzo 1919, ASE,CPA, 357.

68 Ibid. 
is not the same as a territory to be given as a full state with sovereignty". Day did not agree that any form of care that the Albanian state would have after the war, could be used as an argument in favor of the Greek demands.

The Italian Martino, in defense of his government's stance, openly stated that "We have always fought for the independence of Albania. We have always wanted to prevent Austria-Hungary from laying hands on Albania, this is one of the most important differences that we have in this country. Experience has unfortunately shown that the Albanian nation, which despite its image as clear and pure, founded in centuries of history, has no perfect cohesion, and it is likely that it will not be able to resist its neighbors' ambitions, Montenegro, Serbia and Greece. For this reason we think that the Albanian nation needs the support of a power, only in its relations with the outside. This defensive Italian mission for Albania in its relations with the outside is needed, because the Albanian issue is for us an "Adriatic issue of vital interest" ${ }^{\prime 69}$.

The Great Powers and the neighbors might try again to shred Albanian territories, but this time the Conference of Ambassadors in Paris, acted as an organ of the Peace Conference on the implementation of its decisions. It moved the political debate forward about the future of Albania and the confirmation of its legal status internationally. For a range of circumstances, they did not take into account the claims of Athens and Belgrade, for the rectification of borders in the South and the North. Nor did they accept the request for recognition of the "free state of Mirdita, protected and represented in foreign relations" by the Belgrade Government. It also spoke against the enforcement of the promise that was made in terms of Italy's annexation of Vlora and the surrounding hinterland and for putting Albania under its mandate, as defined in the Secret Treaty of London. On 9 November 1921 the Conference adopted the decision that reconfirms the recognition of Albania as an independent and sovereign state. But, under the reasoning that any "violation of Albania's independence could pose a strategic threat to the security of Italy" ${ }^{\prime 7}$ it accepted the persistent request of Rome and recognized its special interest to preserve Albania's independence. In pursuance of this status it entrusted the border protection through a right of direct intervention whenever Italy would judge its interests were threatened. Although officially

69 Ibid.

70 Idea Nazionale, nationalist press in Italy wrote at that time that Albania was not able to defend its territorial integrity, which does not guarantee that the withdrawal of Italy there will be an opportunity to advance to the next place a foreign power. The New York Times, on the 4 july 1920, republished from Albert Gjoka at the Gazeta Albania, on the 15 Agust 2008. 
they reaffirmed its independence, they gave Italy almost the rights of a protectorate by thus deleting a part of its independent status and violating the position of neutrality of the state. The attitude of the Paris Conference on this issue has been commented upon as being influenced by the spirit of the secrecy of the Treaty of London, even by the Italian military proclamation made by the General Jacinto Ferrero in Gjirokastra, on 3 June 1917, as a concession that the ambassadors made to Italy and its insistent demands ${ }^{71}$. It was this decision that was used in an abusive way by Italy to prepare gradually in all directions the ground for the Fascist aggression of 7 April 1939.

The meaning and the content of the decision of 9 November made by the Conference of Ambassadors, was contested by Lord Hardinge of Penshurst, Count Bonin - Longar and Viscont Ishii, representatives of two of the parties. Before signing the decision of 9 November 1921 regarding the borders, they noted that the first paragraph of the preamble was not quite in conformity with the text of the decision, because although it reaffirms, in principle and in its entirety, the route taken in 1913, it includes many local corrections, among which some are a very important stretch. So it is not correct to say, without reservation, that the track was reaffirmed in 1913. Count Bonin-Langare stated that before signing the decision on Albania he felt a duty, on behalf of the government of the British Empire, to call the attention of representatives of the governments of the signatory powers that he felt sorry but that he could not accept that in the first paragraph after the words "is needed to re-affirm" (the track of 1913) should be added the phrase "in principle"72.

With the decision of 9 November 1921, the Conference of Ambassadors in Paris, ended in formal and legal terms the permanent neutrality status of Albania. This act and others of an international legal character approved for Albania in Versailles, in the end, and after the First World War did not mention neutrality or the Capitulations regime. Neutrality as an essential element of Albania's status accorded by the Great Powers in London in 1913 had practically ceased with the onset of the First World War, when Albania became a place d'armes ${ }^{73}$.

71 Il protettorato italiano sull'Albania, at Prassi italiana di diritto internazionale, Istituto di Studi Giuridici Internazionali, Consiglio Nazionale delle Ricerche, Parte VI - Unioni e istituzioni internazionali, Cap. III - Società delle Nazioni e altre organizzazioni internazionali B - Ammissione di Stati alle organizzazioni internazionali, without a date and place of publication.

72 Affaire du Monastère de Saint Naoum, Leyde 1924, p.363, AQSH, v.1921, D.44, p. 357

73 Signature and entry into force of the Secret Treaty of London, which consequently brought a direct declaration of war by Italy against Austria-Hungary, in May 1915, involved the country. Its territory was invaded by the armies of almost all belligerent 
With regard to the neutrality of Albania, in the events that followed World War II and the Nazi invasion, there is an interesting development that deserves to be noted. It happened nearly 23 years later, precisely at the time of its occupation. German Nazis in Tirana called a virtual National Assembly under the Chairmanship of former President Lef Nosi, whose works lasted from 16 to 25 October 1943. They created a regency which included representatives from four of the country's main religious communities. The Kosovar Rexhep Mitrovica became prime minister of Albania with Xhafer Deva as minister of internal affairs and Vehbi Frashëri as deputy of foreign affairs. The so-called National Constitutional Assembly was declared to be the legislative body and it took several decisions, including invalidating all laws and constitutional documents issued after 9 April 1939, cancelling the Albanian crown of the Italian king Victor Emmanuel III, restoring the royal constitution in force in Albania in 1928 etc. $^{74}$ But what interests us is the proclamation again of the neutrality of Albania, a demagogic and fictional gesture, because the country was occupied by the armies of the German Wehrmacht, a situation quite incompatible with the status of neutrality.

states. In June, Albania's North and East were trampled by Serbian and Montenegrin forces, then the Austro-Hungarian armies and later the Bulgarian armies.

74 Historia e popullit shqiptar, IV, Shqiptarët gjatë Luftës së Dytë Botërore dhe pas saj, 1939-1990, Botimet Toena, Tiranë 2008, pp. 83-88 


\section{The importance of the status of Albania}

The issue we are talking about had a special importance for Albania. The governments of neighboring countries, and especially Greece and Serbia, at the Peace Conference, at the League of Nations and at the Conference of Ambassadors came out with the thesis that the independence and neutrality of Albania were forfeit by acts of violation perpetrated by the Greeks and Serbs themselves during the First World War. By pointing out this issue they wanted to re-discuss all Albanian problems with the hope that the time had come to realize their annexation goals unmet in 1913.

The Greek representative at the League of Nations in 1921 insisted that it was Albania which violated its neutrality when Esat Toptani's forces stood beside the Entente in $1914^{75}$. These claims were dismissed with convincing arguments with logic of a legal-international character, by the Albanian delegation in the League of Nations. In the session of 25 June 1921, at the Council of the League of Nations, which was mentioned above, Noli said: "If Esat was truly the president of Albania and he joined the Entente, then Albania should be considered as an ally. Consequently it seems quite impossible that a Peace Conference means not to protect an ally. The thesis that protects the Albanian government is that Albania was neutral during the war"76

Albania's point of view prevailed at the League of Nations. After that and after the adoption of the decision of the Conference of Ambassadors in Paris, on 9 November 1921, the issue of the legal status of Albania was considered resolved. It was already known and accepted as an independent state, subject to full rights of international law, a member of the League of Nations and a number of other international organizations, which did not leave any space for equivocation or abusive interpretations by others.

75 A.Simonard, Essai sur l'independnce albanaise, Paris, 1942, p.377.

76 SdN, Journal Officiel, Septembre 1921, pp. 726-729. 
$* * *$

Ksenofon Krisafi is member of the Albanian Academy of Arts and Sciences as well as Dean of the Law Faculty in European University of Tirana. He is a well known Albanian scholar of Albanian diplomatic history. He has held various positions including: Director of the Legal department, international treaties and consular affairs at the Ministry of Foreign Affairs, Ambassador to the UN Office and the World Trade Organization in Geneva, Secretary General of the Council of Ministers, Diplomatic Advisor of the Prime Minister, member of the Supervisory Council of the Bank of Albania, etc. He was also a member of the European Commission for the Efficiency of Justice of the European Council, a member of the Executive Council of the Inter-University Centre for Research in Eastern and Southeastern Europe , CIRCEO, and a member of the Albanian Helsinki Committee. 